\title{
Effectiveness of Implementing ITE Laws and Investigations of Damnation through Social Media
}

\author{
Satria Ardi Yana ${ }^{*}$ and Bambang Tri Bawono**) \\ *) Student of Master of Law, Faculty of Law, Universitas Islam Sultan Agung (UNISSULA) \\ and Ditreskrimsus Central Java Regional Police, E-mail: satriairin@gmail.com \\ ${ }^{* *}$ Lecturer of Faculty of Law, Universitas Islam Sultan Agung (UNISSULA) Semarang
}

\begin{abstract}
.
Social media is also often used as a place to show off the public to post sparkling luxury. The formulation of the problem and the purpose of this study is the effectiveness of the implementation of the ITE Law and investigations of criminal defamation through social media in the conception of legal certainty.Obstacles and Efforts in the process of investigating criminal defamation through social media based on the ITE Law. The research methodology is a sociological juridical legal approach and the specification in this research is descriptive analytical. The theory used is the theory of legal effectiveness and the theory of legal certainty. The results showed that the handling of criminal defamation through social media based on the ITE Law in society has not been effective. The fact is the increasing number of criminal acts of defamation from year to year, and the mode of crime. The first obstacle is the Search for Perpetrators through social media used by defamation facilities, the two factors of inadequate facilities and infrastructure, the third is the difficulty of disclosing evidence, the fourth is the amount of budget required by the police in the process of proving a case using expert witnesses, and the fifth difference in legal perspectives from Social media founding countries.

Keywords: Investigation, Crime; Social Media.
\end{abstract}

\section{Introduction}

Advances in information and communication technology have given birth to positive contributions to humans in this modern era because they are able to increase progress and help human work. But on the other hand, information and communication technology also creates negative contributions, because with the spread of information and communication technology, one of them is the existence of an internet site that can make it easier for people to access any data they want, so that it can lead to the emergence of new crimes, namely by make use of internet sites as its mode of operation. Several other nicknames or designations given to this new type of crime are cyber crime or cybercrime. ${ }^{1}$ Cybercrime is a type of crime related to the use of unlimited information technology and has strong characteristics with an engineering technology that relies on a high level of security and credibility of information submitted and accessed by internet subscribers. ${ }^{2}$ Social change due to technological advances not only brings positive impacts, but also appears negative in the form of the birth of new forms of crime using information technology facilities. In some literature crimes that use technology are grouped into several forms, including: Un authorized Access to Computer System and Services, Illegal Contents, Data Forgery, Cyber Espionage,

\footnotetext{
${ }^{1}$ Arief, Barda Nawawi. (2007) Tindak Pidana Mayantara. Jakarta: Raja Grafindo Persada.p.1

2 Maskun. (2013). Kejahatan Siber, First Edition. Jakarta: Kencana. p.48
} 
Cyber sabotage and Exortion, Offense Against Intellectual Property, and Infringements of Privacy. ${ }^{3}$

Freedom of expression is part of human rights. Therefore, it is guaranteed by the UN Universal Declaration of Human Rights, he stressed in articles 19 and 20 as written below. 1. Article 19 "Everyone has the right to freedom to have and express opinions, in this matter including freedom to have opinions without interference and to seek, receive and convey information and opinions in any way whatsoever and do not see boundaries". Article 20 Paragraph 1 "Everyone has the right to freedom of assembly and opinion." Verse 2 "No one also can be forced into an association." Along with the development of technology and the rise of social media, the wider freedom of expression in the community. We, as modern creatures, can easily share our thoughts, opinions, arguments on social media. And because social media is broad and open, our opinion can be seen by the wider community. But because of that, sometimes when we feel annoyed or disappointed with a party then unconsciously pour it on social media. Often times we don't realize that something as small as this can be Lex Et Societatis Vol. VI / No. 4 / Jun / 201870 takes us to the realm of law. This is because our freedom of opinion is not free but there are still limitations. The limits referred to here are boundaries that are formed due to the rights of other people as well. Where we as social creatures must respect each other. In other words, freedom of expression must be exercised responsibly. This means that expressing opinions must be based on common sense, goodwill, and norms that apply in society. Thus, the opinion expressed is not only beneficial for himself, but also for other people, society or even for the nation and state. ${ }^{4}$

Case Criminal action is a criminal act that can be punished, any action that is threatened as a crime, a violation both mentioned in the Criminal Code and other laws. ${ }^{5}$ When we want to know the extent of the effectiveness of the law, then we must first be able to measure the extent to which the law is adhered to by most of the targets to which it is obeyed, we will say that the rule of law concerned is effective. However, even though it is said that the rules that are obeyed are effective, we can still further question the degree of their effectiveness because someone obeys or not a rule of law depends on their interests. ${ }^{6}$ As previously stated, there are various kinds of interests, including those of compliance, identification, and internalization. Role is defined as a set of behaviors that are expected to be owned by people in society. The position in this case is expected to be a certain position in society which may be high, moderate or low. Position is a container whose contents are certain rights and obligations, while these rights and obligations can be said to be roles. Therefore, someone who has a certain position

${ }^{3}$ Didik M. Arif, Mansur \& Elisataris Ghultom. (2005). Cyber Law: Aspek Hukum Teknologi Informasi. Bandung: Refika Aditama.p. 9-10

${ }^{4}$ Christyana Olivia Dewi, Dr. Johnny Lembong, SH., MH, Dr. Jemmy Sondakh, SH., MH Perspektif Penanganan Perkara Tindak Pidana Pencemaran Nama Baik Terkait Dengan Impelementasi Hak Kebebasan Berpendapat Ditinjau Dari Hukum Pidana \& Hak Asasi Manusia in jurnal Lex Et Societatis Vol. VI/No. 4/Jun/2018

${ }^{5}$ M. Marwan \& Jimmy P. (2009). Kamus Hukum Dictonary of Law Complate Edition. Surabaya: Reality Publisher.p. 608.

${ }^{6}$ Ali, Achmad. (2009). Menguak Teori Hukum (Legal Theory) \& Teori Peradilan (Judicialprudence) Termasuk Interpretasi Undang-Undang (Legisprudence). Jakarta: Penerbit Kencana. p. 375. 
can be said to be a role holder (role accupant). A right is actually the authority to do or not act, while an obligation is a burden or duty. ${ }^{7}$ Based on the description of the background of the problem above, the problem formulation in this study is How effectiveness of the implementation of Article 27 paragraph (3) of Act No. 19 of 2016 concerning amendments to Act No. 11 of 2008 concerning Electronic Transaction Information in society, How obstacles and efforts to solve them.

\section{Research Methods}

The research method used is a sociological juridical legal approach and the specifications in this study include descriptive analytical. The sources and types of data in this research are primary data obtained from field studies, interviews with witnesses of arresters and investigators in the jurisdiction of the Central Java Regional Police and secondary data obtained from literature studies relating to the theory of legal effectiveness and theory of legal certainty.

\section{Results and Discussion}

Sociologically, roles are dynamic aspects in the form of actions or behaviors carried out by someone who occupies or holds a position and exercises rights and obligations according to their position. If a person carries out this role well, he will naturally hope that what is carried out is in accordance with the wishes of his environment. Role in general is presence in determining a process of continuity. ${ }^{8}$ In addition to being regulated in Article 1 point 1 of the Criminal Procedure Code and Article 6 of the Criminal Procedure Code, there is another Article 10 which regulates the existence of an assistant investigator in addition to the investigator. ${ }^{9}$ Meanwhile Soerjono Soekanto used the measure of internal effectiveness enforcement law on five things, namely: ${ }^{10}$

- Legal Factors

- Law Enforcement Factors

- Supporting Facility or Facility Factor

- Community Factors

- Cultural Factors

The five factors above are closely related, because they are the main thing in law enforcement, as well as a measure of the effectiveness of law enforcement. Of the five factors of law enforcement, the law enforcement factor itself is the central point. This is due to the fact that laws are drafted by law enforcers, law enforcement is also implemented by law enforcers and law enforcement itself is also a role model for the wider community. ${ }^{11}$

\footnotetext{
${ }^{7}$ Bakir, R. Suyoto. (2009). Kamus lengkap Bahasa Indonesia. Tengerang: Karisma Publishing Group.p. 348.

8Soekanto, Soerjono. (2002). Sosiologi Suatu Pengantar. Jakarta: Rajawali Press.p. 242.

9Harahap, M. Yahya. (2000). Pembahasan Permasalahan \& Penerapan KUHAP, Penyidikan \& Penuntutan, prit. VII, Jakarta: Sinar Grafika.p. 110

${ }^{10}$ Soekanto, Soerjono. (2007). Faktor-Faktor yang Mempengaruhi Penegakan Hukum. Jakarta: Penerbit PT. Raja Grafindo Persada.p. 5.

${ }^{11}$ Rohmah, Iffa. (2016). Penegakkan Hukum. http://pustakakaryaifa.blogspot.com. Accessed on June 8, 2020
} 
Based on the results of the study, the handling of criminal defamation through social media based on Act No. 19 of 2016 concerning amendments to Act No. 11 of 2008 concerning ITE in society has not been effective. This is manifested by the increase in the number of criminal acts of defamation from year to year, and the variety of modes of criminal acts. Obstacles in Enforcement of the Crime of Defamation in the Central Java Regional Police, namely, first the search for the perpetrator through social media used for defamation, the second is inadequate facilities and infrastructure, the third is the difficulty of disclosing evidence, the fourth is the amount of the budget required by the party. The police in the process of proving cases using expert witnesses, and the five differences in legal perspectives from the founding countries of social media.

There are 9 (nine) points given by Satjipto Rahardjo, regarding the role of the police in responding to the social changes that are taking place, namely: 12

- The police must study for various information (to share information). In connection with this, Toffler said that knowledge is a very dominant force in responding to the various social changes that occur in society, shifting the forces of violence and prosperity that ruled in the 20th century. The police should master the most up-to-date knowledge.

- This demand relates to the obligation of the police to act as a referral service for other agencies that must provide social and cultural services to the community.

- The Police Executive should not be satisfied and let himself be happy with what he has accomplished in the past.

- The police should not see themselves as a work force just like that, but rather position themselves as an integral part of their environment and become members that their environment \pm professionals always look for.

- Referring to Toffler, today's police must be protagonists (with society), not antagonists (against society).

- A good way to do this is to integrate with existing social networks. To be able to do this, the police should reflect on the nature of social change.

- The concept and foundation of the social network must be expanded into cooperation or dependence of the police on community participation.

- The police should be the facilitators of change. Such an attitude is difficult if he is only a guardian of the status quo, as is usually the case with traditional police.

- The law enforcement executives of today must shape the future, and for that they must be the leaders of the future, and for that they must always be one step ahead of their nation / society.

\subsection{Persepective of Damnation in Islam}

First, Maqāşid al-dharuriyat, Imam Juwayniy has argued, which was later developed by Al-Ghozali and asy-Syatibi to maintain al-Umurdh-dharuriyah in human life, namely things that are the foundation of human existence for which there must be benefit to them. That is all the Shari'a which are covered in five 12 Rahardjo, Satjipto. (1999). Peningkatan Wibawa Hukum Melalui Pembinaan Budaya Hukum.
Jakarta: Majalah Hukum Nasional, Nomor 1, BPHN 
things, al-kulliyyat alkhams. ${ }^{13}$ The laws for maintaining al-Umurdh-dharuriyah ${ }^{14}$ that is:

- Hifz al-din (protection of religion)

- Hifz al-nafs (protection of the soul)

- Hifz al-'aql (protection against reason)

- Hifz al-mal (protection of property)

- Hifz al-nasl wa al-'ird (protection of honor and descent)

\subsection{Effectiveness of the Implementation of Article 27 Paragraph (3) of Act No. 19 of 2016 concerning Amendments to Act No. 11 of 2008 Concerning Electronic Transaction Information in the Community}

The times in the digitalization era are very dependent on the use of gadgets. Various kinds of gadget functions are created by various industries to facilitate communication and make habbit in everyday life. This is done as a trend or lifestyle to show someone's prestige in using gadgets as a measure, especially for millennials. Millennials often upload and upload photos and videos in various daily activities.

Meanwhile, Soerjono Soekanto used five measures of effectiveness in law enforcement, namely ${ }^{15}$ :

\subsubsection{Legal Factors}

Act No. No. 19 of 2016 concerning Amendments to Act No. Number 11 of 2008 concerning Electronic Information and Transactions can be said to be a new law among the public. So that the implementation has not been maximized due to constraints on understanding from the community about this law. So that there are many cases related to violations committed by the public regarding this law, especially in Article 27 paragraph (3) concerning defamation.

\subsubsection{Law Enforcement Factors}

Defamation in the ITE Law as described in article 45 paragraph (5) is a complaint offense. Where in the enforcement process the Police cannot enforce the law against violations of defamation cases if there are no reports from those who feel aggrieved over the case. And the rampant cases of defamation among the elite which are often reported in mainstream media such as social media, print media and electronic media, tend to make the public report incidents of defamation a little, although it is not certain that what is reported fulfills the elements of defamation or not.

\subsubsection{Supporting Facility or Facility Factor}

The means of tools owned by the Police in disclosing defamation cases that are not yet maximal tend to reduce the crime clearance rate, which is not proportional to the number of reports on defamation cases.

\footnotetext{
${ }^{13}$ Ahmad Mursi Husain Jauhar, Maqashid Syariah, trans Khikmawati, p XV

14 Ibid. p. 131

${ }^{15}$ Soekanto, Soerjono. (2007). Faktor-Faktor yang Mempengaruhi Penegakan Hukum. Jakarta: Penerbit PT. Raja Grafindo Persada.p. 5.
} 


\subsubsection{Community Factors}

The level of compliance and low legal awareness among the community today tends to increase the number of defamation. Underestimating the prevailing laws and regulations have made many people commit violations or criminal acts which in fact some people are aware of the impact of their actions.

\subsubsection{Cultural Factors}

Differences in the culture of each community and customary rules also influence the development of the number of cyber crimes, especially in cases of defamation.

The five factors above are closely related, because they are the main thing in law enforcement, as well as a measure of the effectiveness of law enforcement. Of the five factors of law enforcement, the law enforcement factor itself is the central point. This is due to the fact that laws are drafted by law enforcers, law enforcement is also implemented by law enforcement and law enforcement itself is also a role model for the wider community.

This is evidenced by the large number of cases reported by the public to the Central Java Regional Police's Ditreskrimsus which is getting higher every year. The following is a diagram of a comparison of the number of defamation cases handled by Central Java Police's Ditreskrimsus investigators from January 2018 to May 2020.

In 2018 there were 27 public complaint letters and 5 police reports on defamation. Meanwhile, in 2019 there were 33 complaint letters and 5 police reports on defamation. Then in 2020 from January to May there are 36 community complaint letters and 2 police reports. This represents a significant increase in public defamation cases. Which from just 5 months from January 2020 to May

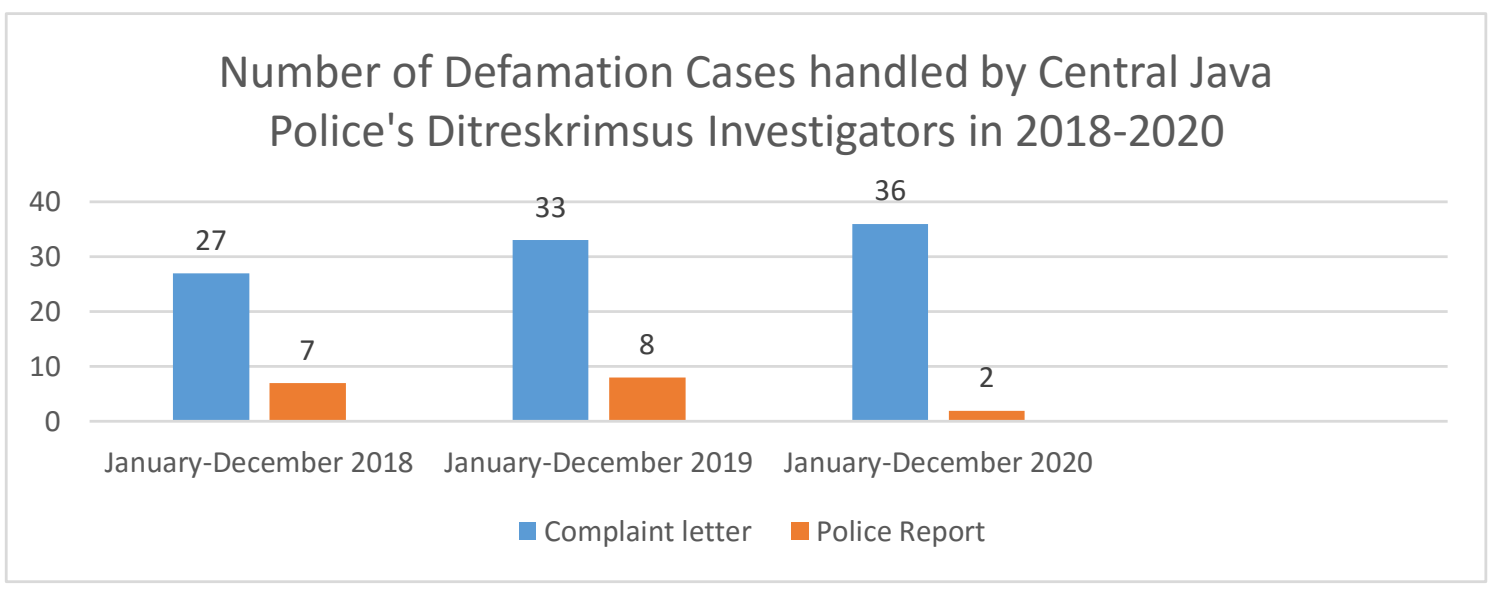

2020 there were 36 public complaint letters and more from 2019 and 2018.

The high number and increasing cases of defamation from year to year are a form of the ineffectiveness of Act No. 19 of 2016 concerning amendments to Act No. 11 of 2008 concerning Electronic Transaction Information in society that is not in accordance with the objectives of the ITE Law, among others, to educating the nation's life, developing national trade and economy, increasing the effectiveness and efficiency of public services and providing a sense of security, justice and legal certainty for users of information technology. 


\subsection{Obstacles and Efforts in the Process of Investigating the Crime of Defamation through Social Media Based}

Gustav Radbruch stated 4 (four) basic things related to the meaning of legal certainty ${ }^{16}$, that is :

- First, that law is positive, meaning that positive law is legislation.

- Defamation cases are closely related to having a legal basis, namely Act No. 19 of 2016 concerning Amendments to Act No. 11 of 2008 concerning Electronic Transaction Information

- Second, that law is based on facts, meaning that it is based on reality.

- Defamation cases are based on facts found on social media in the form of chat chit chat, photos, pictures, and sounds or videos that have been uploaded by the perpetrator so that they can be further reviewed.

- Third, that facts must be formulated in a clear manner so as to avoid mistakes in meaning, as well as being easy to implement.

- Many of the cases of defamation that originate from conflicts in advance and disagree so that they do not solve the problem then the problem is spread in cyberspace, causing virality and it is known that many people lead public opinion so that it can result in defamation of many parties that can be harmed, namely material loss and non material.

- Fourth, positive law cannot be easily changed. Gustav Radbruch's opinion is based on his view that legal certainty is certainty about the law itself.

We have obtained laws that have been regulated in the law based on the investigation process and all related parties can be used that the legal basis can be useful in analyzing cases that are currently happening and become a guide in the investigation process. Legal certainty is a matter (situation) that is certain, provisions or provisions. The law must in essence be sure and fair. Certainly as a code of conduct and fairness because the code of conduct must support an order that is considered reasonable. Only because it is fair and implemented with certainty can the law carry out its function. Legal certainty is a question that can only be answered normatively, not sociologically. ${ }^{17}$

\section{Conclusion}

Criminal law policies against criminal acts today such as information technology before the enactment of Act No. 11 of 2008 concerning Electronic Information and transactions, there are several legal provisions related to the use and misuse of information technology regulated in the Criminal Code and several laws outside the Criminal Code. . The formulation of the previous statute policies of the ITE Law stated that both in terms of criminalization, types of criminal sanctions, formulations of criminal sanctions, subjects and criminal qualifications

\footnotetext{
16 Susanto, Nur Agus. (2012). Dimensi Aksiologis Dari Putusan Kasus "ST" Kajian Putusan Peninjauan Kembali Nomor 97 PK/Pid.Sus/2012, Jurnal Yudisial Vol. 7 No. 3 Desember

2014.

17 Rato, Dominikus. (2010). Filsafat Hukum Mencari: Memahami \& Memahami Hukum Yogyakarta: Laksbang Pressindo. p.59
} 
of different acts, especially in terms of criminal policies that were not regulated explicitly and clearly on Information Technology crimes. ${ }^{18}$

\section{References}

Journals:

[1] Christyana Olivia Dewi, Dr. Johnny Lembong, SH., MH, Dr. Jemmy Sondakh, SH., MH Perspektif Penanganan Perkara Tindak Pidana Pencemaran Nama Baik Terkait Dengan Impelementasi Hak Kebebasan Berpendapat Ditinjau Dari Hukum Pidana \& Hak Asasi Manusia in jurnal Lex Et Societatis Vol. VI/No. 4/Jun/2018

[2] Morradi, Kebijakan Penegakan Hukum Pidana Dalam Upaya Pencegahan Tindak Pidana Teknologi Informasi, Jurnal Daulat Hukum, Vol 2, No 2 (2019)

[3] Susanto, Nur Agus. (2012). Dimensi Aksiologis Dari Putusan Kasus "ST" Kajian Putusan Peninjauan Kembali Nomor 97 PK/Pid.Sus/2012, Jurnal Yudisial Vol. 7 No. 3 Desember

Books:

[1] Ali, Achmad. (2009). Menguak Teori Hukum (Legal Theory) \& Teori Peradilan (Judicialprudence) Termasuk Interpretasi Undang-Undang (Legisprudence). Jakarta: Penerbit Kencana

[2] Arief, Barda Nawawi. (2007) Tindak Pidana Mayantara. Jakarta: Raja Grafindo Persada

[3] Bakir, R. Suyoto. (2009). Kamus lengkap Bahasa Indonesia. Tengerang: Karisma Publishing Group

[4] Didik M. Arif, Mansur \& Elisataris Ghultom. (2005). Cyber Law: Aspek Hukum Teknologi Informasi. Bandung: Refika Aditama

[5] Harahap, M. Yahya. (2000). Pembahasan Permasalahan \& Penerapan KUHAP, Penyidikan \& Penuntutan, prit. VII, Jakarta: Sinar Grafika

[6] M. Marwan \& Jimmy P. (2009). Kamus Hukum Dictonary of Law Complate Edition. Surabaya: Reality Publisher

[7] Maskun. (2013). Kejahatan Siber, First Edition. Jakarta: Kencana

[8] Rahardjo, Satjipto. (1999). Peningkatan Wibawa Hukum Melalui Pembinaan Budaya Hukum. Jakarta: Majalah Hukum Nasional, Nomor 1, BPHN

[9] Rato, Dominikus. (2010). Filsafat Hukum Mencari: Memahami \& Memahami Hukum Yogyakarta: Laksbang Pressindo

[10] Soekanto, Soerjono. (2002). Sosiologi Suatu Pengantar. Jakarta: Rajawali Press

[11] Soekanto, Soerjono. (2007). Faktor-Faktor yang Mempengaruhi Penegakan Hukum. Jakarta: Penerbit PT. Raja Grafindo Persada

Internet:

1. Rohmah, Iffa. (2016). Penegakkan Hukum. http://pustakakaryaifa.blogspot.com Accessed on June 8, 2020

18 Morradi, Kebijakan Penegakan Hukum Pidana Dalam Upaya Pencegahan Tindak Pidana Teknologi Informasi, Jurnal Daulat Hukum, Vol 2, No 2 (2019) 